$$
\begin{gathered}
\text { Military Technical College } \\
\text { Kobry El-Kobbah, } \\
\text { Cairo, Egypt }
\end{gathered}
$$

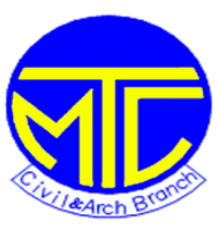

\section{$12^{\text {th }}$ International Conference \\ on Civil and Architecture \\ Engineering \\ ICCAE-12-2018}

\title{
ASSESSMENT OF HYDROLOGICAL ANALYSIS USING WMS VERSUS ARC-GIS
}

\author{
Mohamed M. Kamal ${ }^{1}$, Hassan E. Elhifnawy ${ }^{2}$, Ahmed S. Elsharkawy ${ }^{2,}$ Osama M. Mousa ${ }^{2}$ \\ ${ }^{1}$ Military Engineering Department, Egyptian Armed Forces, Cairo, Egypt \\ ${ }^{2}$ Civil Engineering Department, Military Technical College, Cairo, Egypt
}

\begin{abstract}
:
Hydrological models were applied to extract watersheds and to investigate rainfall computations. There are different techniques for hydrological terrain models. Watershed Modeling System (WMS) and ARC-GIS are commonly used software to simulate and analyse terrain model for extracting watersheds. This research paper applied hydrological models for using two techniques in WMS and ARC-GIS software and extracted a comparative study area between the results of the two different techniques.
\end{abstract}

Storing water in natural or artificial reservoirs are important for barring water to be useful in many applications as electrical, suppress floods, irrigation, human consumption, industrial use, aquaculture, and navigability. The failure of dam structures may cause disasters loss of life when they occur, so dams are considered as installations containing dangerous forces due to the massive impact of a possible destruction on the civilian population and the environment. Failure of dam is a case study for this research paper. A hydrological model is applied to investigate the track of water flow after dam failure of the dam.

Available data is $30 \mathrm{~m}$ Digital Elevation Model (DEM) for the study area, extracted from Shuttle Topographic Rader Mission (STRM). The hydrological mode (HEC 1) was applied to simulate surface runoff, watersheds that is used in calculating the amount of water stored behind the dam. The research tested the techniques by using two commonly software, WMS and ARC-GIS.

The research investigated the comparative between using water shed modelling system (WMS), (Arc-GIS) to extract watershed, water basin of the study area.

The difference between results of the two techniques shows that the calculations by ARC-GIS are more accurate than calculations by WMS.

KEYWORDS: Hydrology, Watersheds, WMS, ARC-GIS 


\section{INTRODUCTION}

A Dam is a barrier across flowing water that obstructs, directs or slows down the flow, often creating a reservoir, lake or impoundments. Most dams have a section called a spillway or weir over or through which water flows, either intermittently or continuously, and some have hydroelectric power generation systems installed.

Dams are considered "installations containing dangerous forces" under International Humanitarian Law due to the massive impact of a possible destruction on the civilian population and the environment. Dam failures are comparatively rare, but can cause immense damage and loss of life when they occur. In 1975 the failure of the Banqiao Reservoir Dam and other dams in Henan Province, China caused more casualties than any other dam failure in history. The disaster killed an estimated 171,000 people [1] and 11 million people lost their homes.

Main causes of dam failure are: Sub-standard construction materials/techniques, Spillway design error, Geological instability etc. On the other hand, a notable cases of deliberate dam failure were historically registered during the World War II, the British Royal Air Force Dam busters raid on Germany and the Chinese bombing of multiple dams during Typhoon Nina (1975) in an attempt to drain them before their reservoirs overflowed.

Digital Elevation Model (DEM) for the study area, extracted from shuttle Topographic Rader Mission (STRM) was used to delineate the boundary of the required watershed by using WMS and ARCGIS in order to determine area of the watershed.

\section{THE STUDY AREA}

The Aswan Dam is an embankment dam built across the Nile in Aswan, Egypt, between 1960 and 1970. Its significance largely eclipsed the previous Aswan Low Dam initially completed in 1902 downstream. Based on the success of the Low Dam, then at its maximum utilization, construction of the High Dam became a key objective of the government following the Egyptian Revolution of 1952; with its ability to control flooding better, provide increased water storage for irrigation and generate hydroelectricity the dam was seen as pivotal to Egypt's planned industrialization. Like the earlier implementation, the High Dam has had a significant effect on the economy and culture of Egypt.

Before the High Dam was built, even with the old dam in place, the annual flooding of the Nile during late summer had continued to pass largely unimpeded down the valley from its East African drainage basin. These floods brought high water with natural nutrients and minerals that annually enriched the fertile soil along its floodplain and delta; this predictability had made the Nile valley ideal for farming since ancient times. However, this natural flooding varied, since high-water years could destroy the whole crop, while lowwater years could create widespread drought and associated famine. Both these events had continued to occur periodically. As Egypt's population grew and technology increased, both a desire and the ability developed to completely control the flooding, and thus both protect and support farmland and its economically important cotton crop. With the greatly increased reservoir storage provided by the High Aswan Dam, the floods could be controlled and the water could be stored for later release over multiple years. 


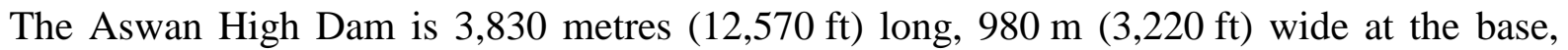

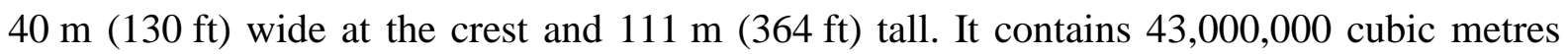
$(56,000,000 \mathrm{cu} \mathrm{yd})$ of material. At maximum, 11,000 cubic metres per second $(390,000 \mathrm{cu} \mathrm{ft} / \mathrm{s})$ of water can pass through the dam. There are further emergency spillways for an extra 5,000 cubic metres per second $(180,000 \mathrm{cu} \mathrm{ft} / \mathrm{s})$, and the Toshka Canal links the reservoir to the Toshka Depression. The reservoir, named Lake Nasser, is $550 \mathrm{~km}$ (340 mi) long and $35 \mathrm{~km}(22 \mathrm{mi})$ at its widest, with a surface area of 5,250 square kilometres $(2,030 \mathrm{sq} \mathrm{mi})$. It holds 132 cubic kilometres $(1.73 \times 1011 \mathrm{cu}$ yd $)$ of water.

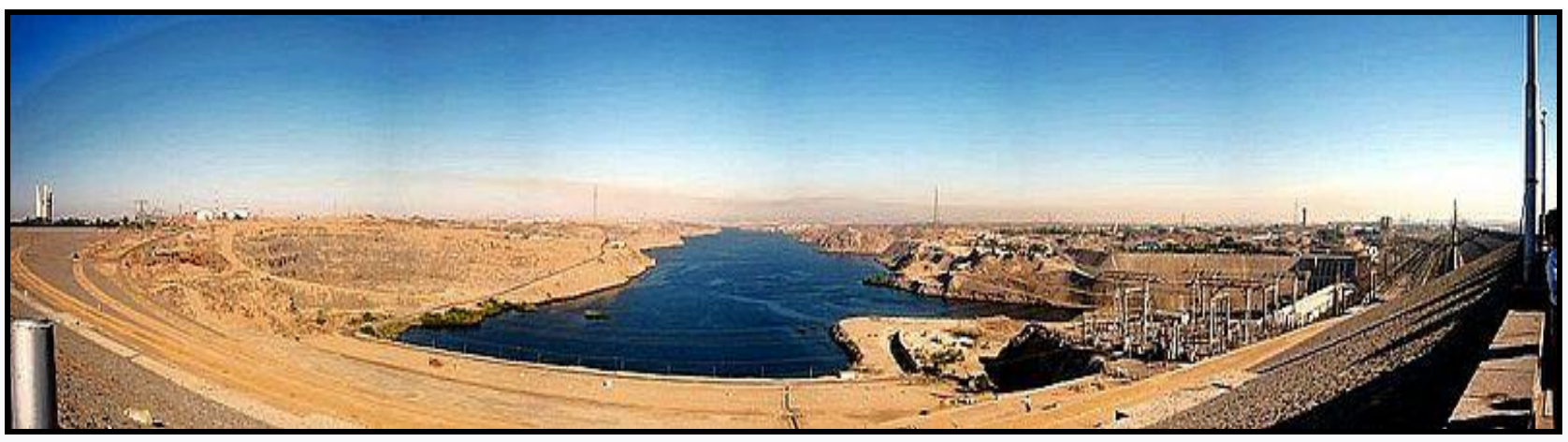

panorama of the Aswan Dam

\section{ASWAN HIGH DAM RESERVOIR}

Aswan High Dam Reservoir extends for $500 \mathrm{~km}$ along the Nile River and covers an area of 6,000 $\mathrm{km} 2$, of which northern two-thirds (known as Lake Nasser) is in Egypt and one-third (called Lake Nubia) in Sudan.

The dam, completed in 1968 at a distance of $7 \mathrm{~km}$ south of Aswan City, is a rockfill dam made of granite rocks and sands and provided with a vertical cutoff wall consisting of very impermeable clay.

The structure is 2,325 m long, $111 \mathrm{~m}$ high over the original river bed, and $40 \mathrm{~m}$ and $980 \mathrm{~m}$ wide, respectively, at its crest and bottom. Nile flow is allowed to pass only through the open-cut channel at the eastern side of the dam, where six tunnel inlets provided with steel gates are constructed for discharge control and water supply to power plants. An escape is also provided at the western side of the dam to permit excess water discharge.

The long reservoir has 100 side arms called khors, more on the eastern shore than on the western shore. The total capacity of the reservoir $(162 \mathrm{~km} 3)$ consists of the dead storage of $31.6 \mathrm{~km} 3(85$ $147 \mathrm{~m}$ a.s.l. of lake water level), the active storage of $90.7 \mathrm{~km} 3(147174 \mathrm{~m})$ and the emergency storage for flood protection of $41 \mathrm{~km} 3(175182 \mathrm{~m})$. The reservoir is surrounded by rocky desert terrain. To the west is the great Sahara Desert, and the Eastern Desert on the east side extends to the Red Sea.

The Aswan High Dam contributed greatly to the economic development of Egypt by supplying 15\% more irrigation water and about 2,000 MW hydroelectricity and protecting the lower reaches of the Nile from flood disasters. On the other hand, however, its environmental impacts were serious. The 
rapid siltation near the head of the reservoir may dam up the narrow Nile valley in Nubia in a

relatively short time. Whereas floods have been prevented along the Nile, the erosion increased along its lower courses and the transgression of Nile delta on the Mediterranean coast is taking place.

The loss of soil fertility and the increase of soil salinity are noticed in cultivated fields along the Nile owing to the cease of annual silt and flood water supply.

\section{PHYSICAL DIMENSIONS}

Surface area [km2] 6,000

Volume [km3] 162

Maximum depth [m] 110

Mean depth [m] 70

Water level Regulated

Normal range of annual water level

fluctuation [m] 25

Length of shoreline [km] ca. 9,000

Catchment area [km2] 2,849,000

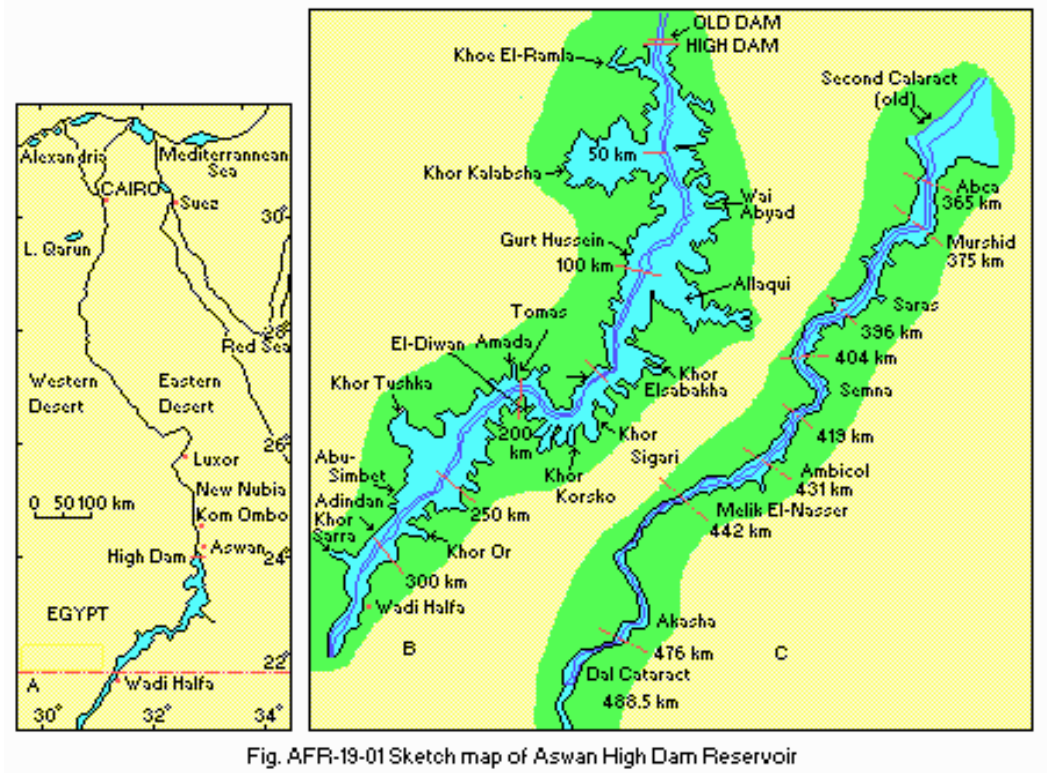

\section{Main causes of dam failure}

- Sub-standard construction materials/techniques (Gleno Dam)

- Spillway design error (South Fork Dam, near failure of Glen Canyon Dam)

- Geological instability caused by changes to water levels during filling or poor surveying (Malpasset Dam).

- Sliding of a mountain into the reservoir (Vajont Dam - not exactly a dam failure, but caused nearly the entire volume of said reservoir to be displaced and overtop the dam)

- Poor maintenance, especially of outlet pipes (Lawn Lake Dam, Val di Stava dam collapse)

- Extreme inflow (Shakidor Dam)

- Human, computer or design error (Buffalo Creek Flood, Dale Dike Reservoir, Taum Sauk pumped storage plant)

- Internal erosion or piping, especially in earthen dams (Teton Dam)

- Earthquakes

Other causes of dam failure are by using Air Force, case of deliberate dam failure (prior to the Humanitarian Law rulings) was the British Royal Air Force Dam busters raid on Germany in World War II (codenamed "Operation Chastise"), in which three German dams were selected to be breached in order to impact on German infrastructure and manufacturing and power capabilities deriving from the Ruhr and Eder rivers. This raid later became the basis for several films.

Other cases include the Chinese bombing of multiple dams during Typhoon Nina (1975) in an attempt to drain them before their reservoirs overflowed. The typhoon produced what is now considered a 1-in-2000 year's flood, which few if any of these dams were designed to survive. 


\section{METHODOLGY}

In this research we will study the effect of failure of Aswan High dam on the NILE valley.

In order to avoid the consequences of this disaster, the amount of water stored behind the dam, which is expected to flow, is calculated to get the optimum pass for diverging the water outwards the NILE valley.

Based on the knowledge of the amount of water stored in Lake Nasser and expected to flow if the collapse of the dam appears. The level of the ground in front of the High Dam will be studied and the calculation of the area of the basins is carried out in order to determine the effective surface flow and sediments accompanied by using digital elevation model with a resolution 30 meters.

\subsection{DIGITAL ELEVATION MODELS (DEM)}

The available data is 30m digital elevation model (DEM) for study area from shuttle Topographic Rader Mission (STRM).

Digital Elevation Models (DEM) offer an efficient way to represent ground surface and allow automated direct extraction of hydrological features, thus bringing advantages in terms of processing efficiency, cost effectiveness and accuracy assessment, compared with traditional methods based on topographic maps, field surveys or photographic interpretations. For the last few decades, DEMs are widely used for resource management, urban planning, transportation planning, earth sciences, and environmental assessments and Geographic Information System (GIS) applications. In this study the raster DEM is used as a base map layer to derive the topographic attributes of the watershed such as area, slope and field slope length. Resolution of elevation data represents the horizontal accuracy of a DEM. An issue with the topography based hydrologic modeling has been that at what spatial resolution a model would perform optimally.

\subsection{GEOGRAPHIC INFORMATION SYSTEM (GIS)}

Arc-GIS is a geographic information system (GIS) for working with maps and geographic information. It is used for creating and using maps, compiling geographic data, analysing mapped information, sharing and discovering geographic information, using maps and geographic information in a range of applications, and managing geographic information in a database.

The system provides an infrastructure for making maps and geographic information available throughout an organization, across a community, and openly on the Web.

ArcGIS includes the following Windows desktop software:

- Arc Reader, which allows one to view and query maps created with the other ArcGIS products;

- ArcGIS for Desktop, which is licensed under three functionality levels:[3]

- ArcGIS for Desktop Basic (formerly known as ArcView), which allows one to view spatial data, create layered maps, and perform basic spatial analysis;

- ArcGIS for Desktop Standard (formerly known as Arc Editor), which in addition to the functionality of ArcView, includes more advanced tools for manipulation of shape files and geodatabases;

- ArcGIS for Desktop Advanced (formerly known as Arc Info), which includes capabilities for data manipulation, editing, and analysis.

There are also server-based ArcGIS products, as well as ArcGIS products for PDAs. Extensions can be purchased separately to increase the functionality of ArcGIS. 


\subsection{WATERSHED MODELLING SYSTEM (WMS)}

The Watershed Modelling System (WMS) is a proprietary water modelling software application used to develop watershed computer simulations. The software provides tools to automate various basic and advanced delineations, calculations, and modelling processes.[1] It supports river hydraulic and storm drain models, lumped parameter, regression, 2D hydrologic modelling of watersheds, and can be used to model both water quantity and water quality. As of January 2017 , supported models include HEC-1, HEC-RAS, HEC-HMS, TR-20, TR-55, NFF, Rational, MODRAT, HSPF, CE-QUAL-W2, GSSHA, SMPDBK, and other models.

\section{DATA ACQUISITION}

\subsection{DIGITAL ELEVATION MODEL}

1- Downloading 30m DEM image for Aswan city from shuttle Topographic Rader Mission (STRM).

2- Project Raster image which Transforms the raster dataset from (LAT,LONG) projection to (WGS_1984_UTM_Zone_36N) projection

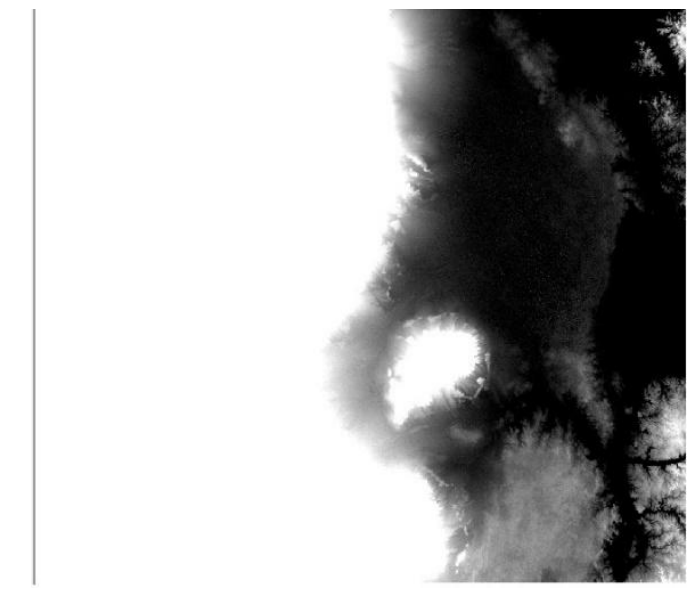

DEM before projection

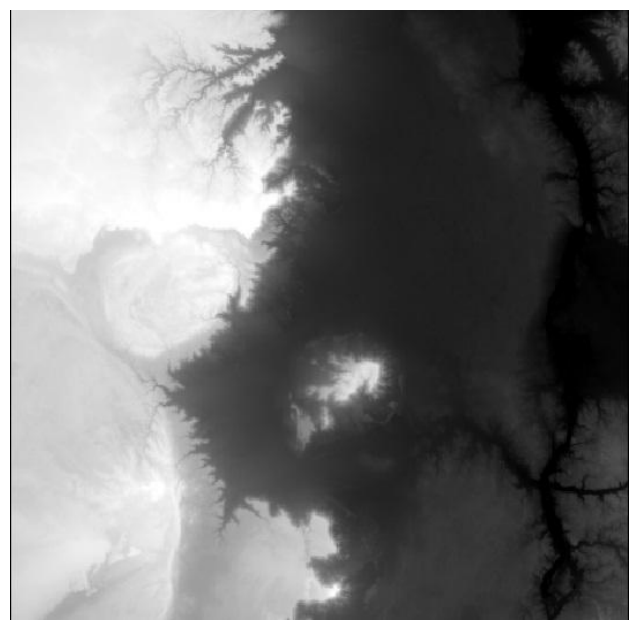

DEM after projection

3- Insert projected image in ArcGis \& WMS programs

\subsection{WATERSHED MODELLING SYSTEM (WMS)}

- In this model we insert the projected image after conversion a raster dataset to an ASCII text file representing raster data.

- Transform the dataset from (lat, long) projection to WGS_1984_UTM projection system to $(\mathrm{E}, \mathrm{N}, \mathrm{H})$ coordinate.
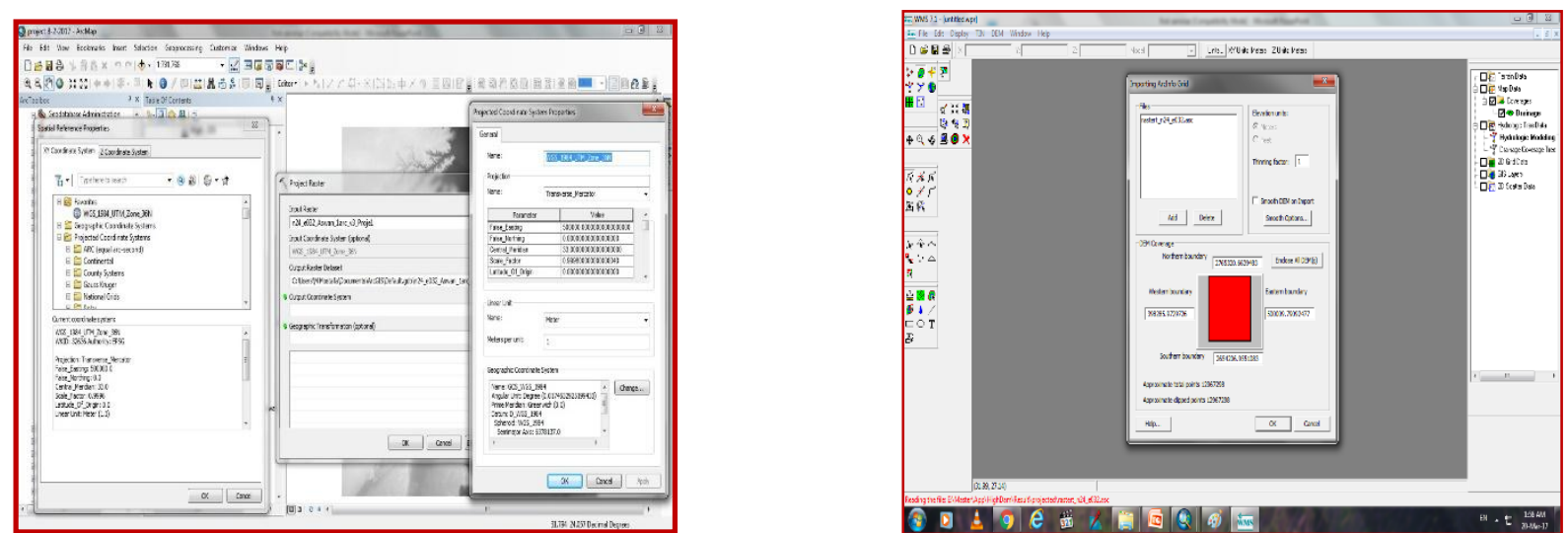
- Read corrected DEM by WMS to extract the watersheds of the area of study.

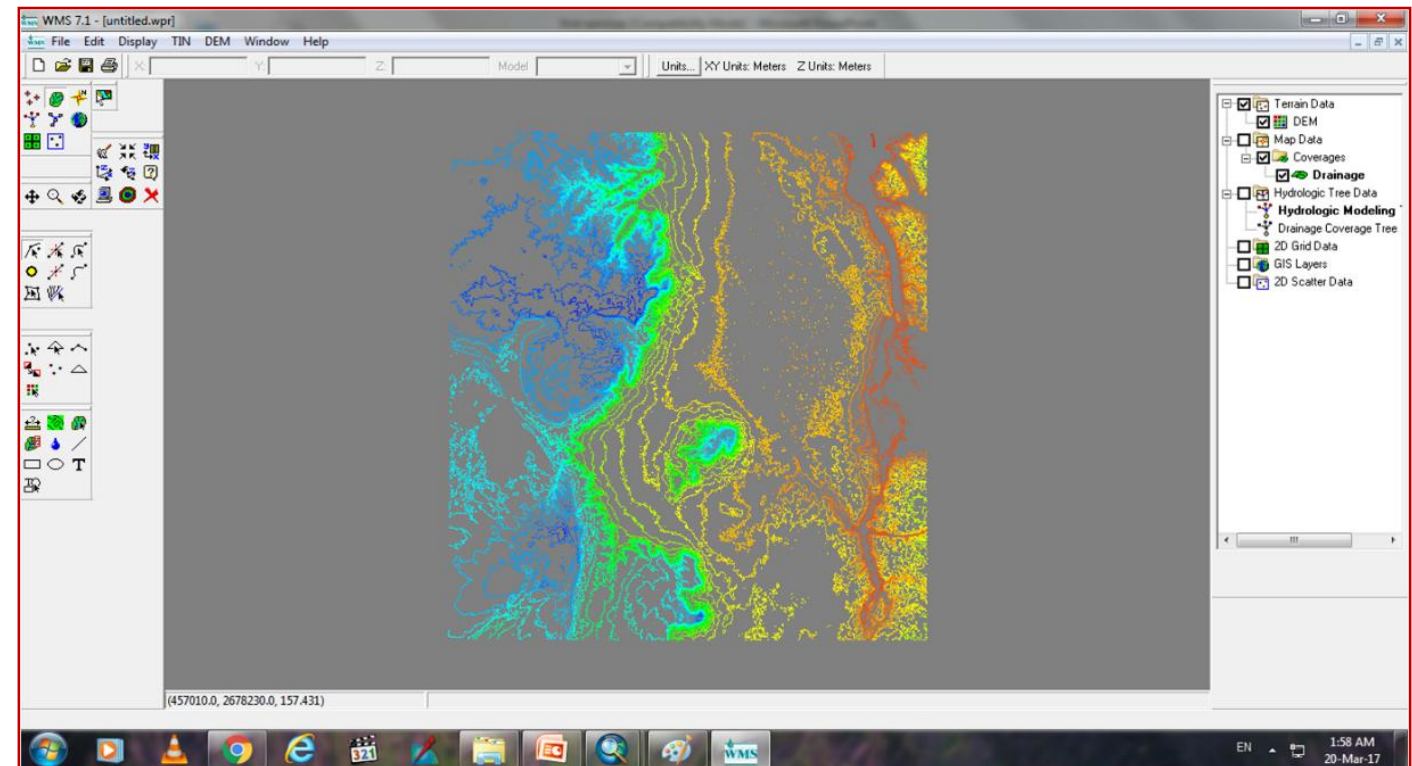

- Extract water drainage, Define basin through watershed.

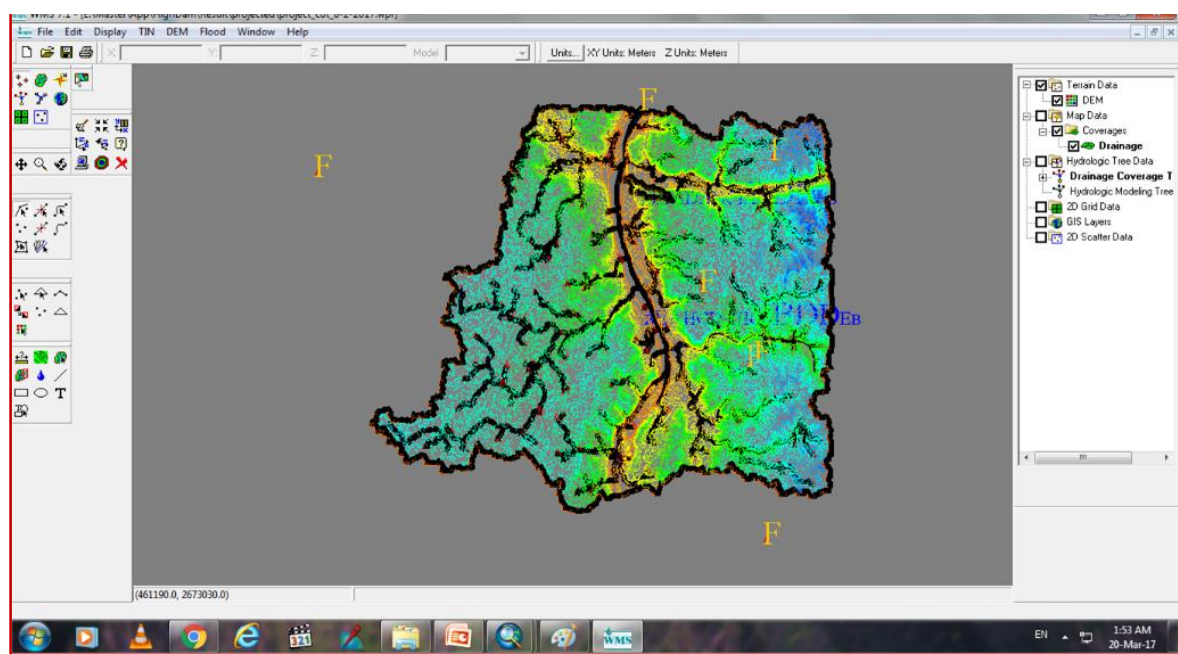




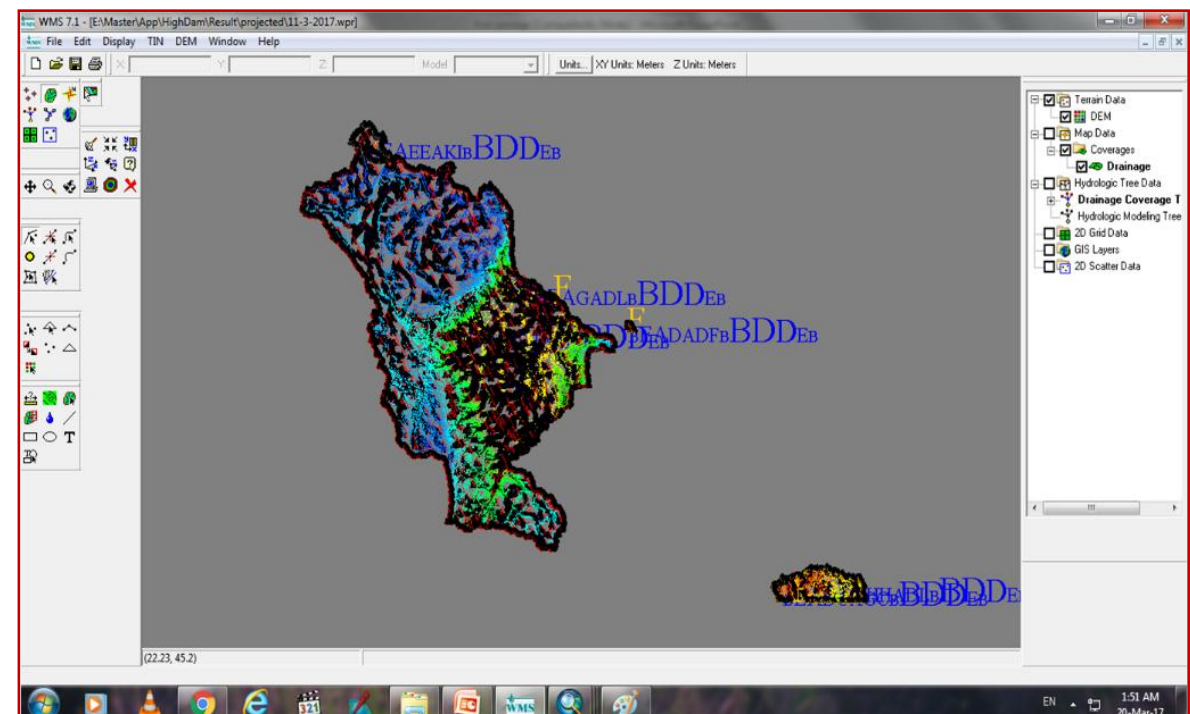

- Calculate the area of basins to accommodate the water flooded from the AHD reservoir.

\subsection{GEOGRAPHIC INFORMATION SYSTEM (GIS)}

- In this case we insert the projected image in Arc-GIS model and Transform the dataset from (lat, long) projection to WGS_1984_UTM projection system to (E,N,H) coordinate.

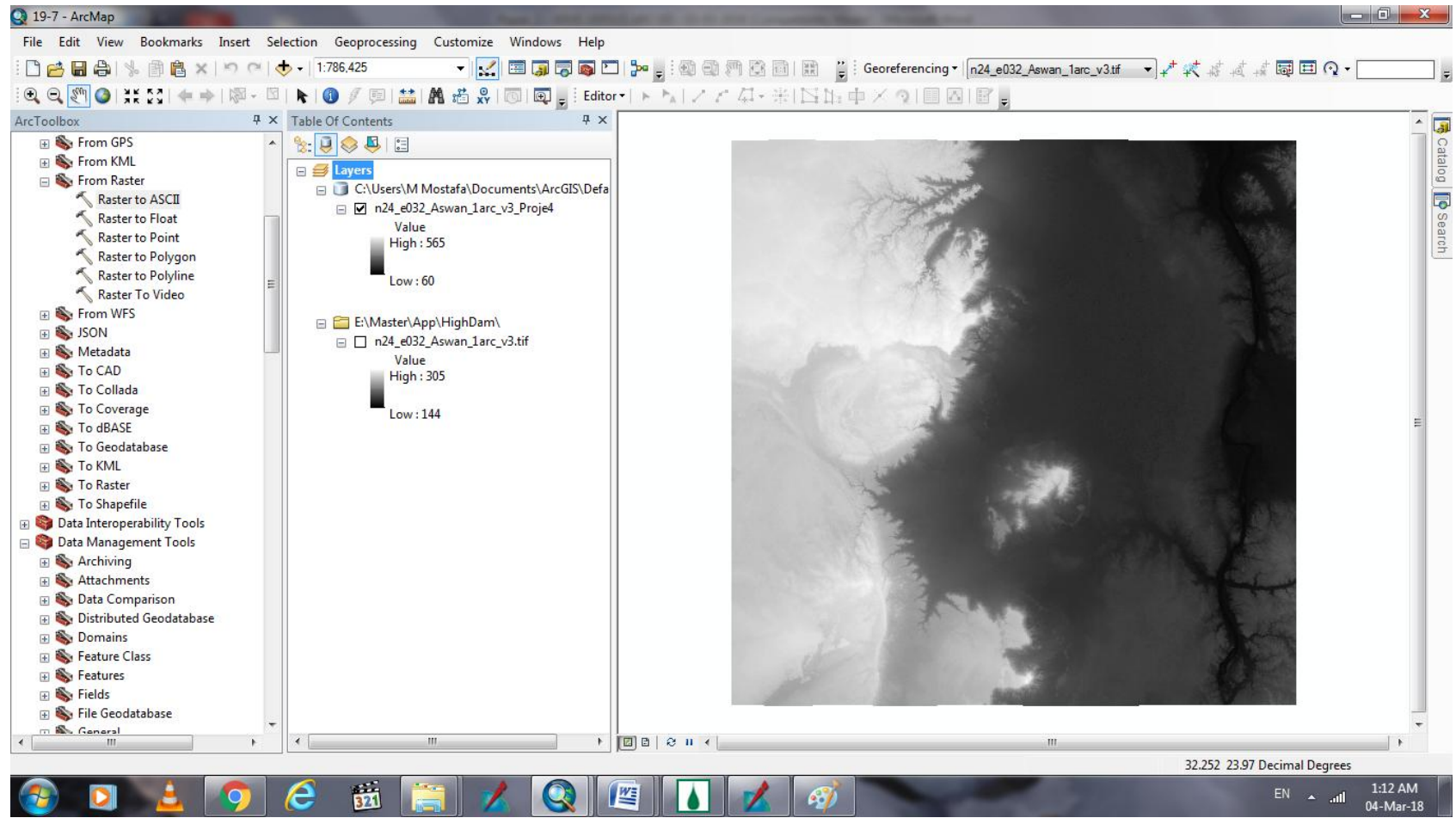

- From spatial analysis tool we select Hydrology which consist the following:

Basin - Fill - flow Accumulation - Flow Direction - flow Length - Watershed ...etc

- After processing the ArcGIS model is delineate the boundary of the watershed which will used to collect the water flooded from Aswan reservoir. 


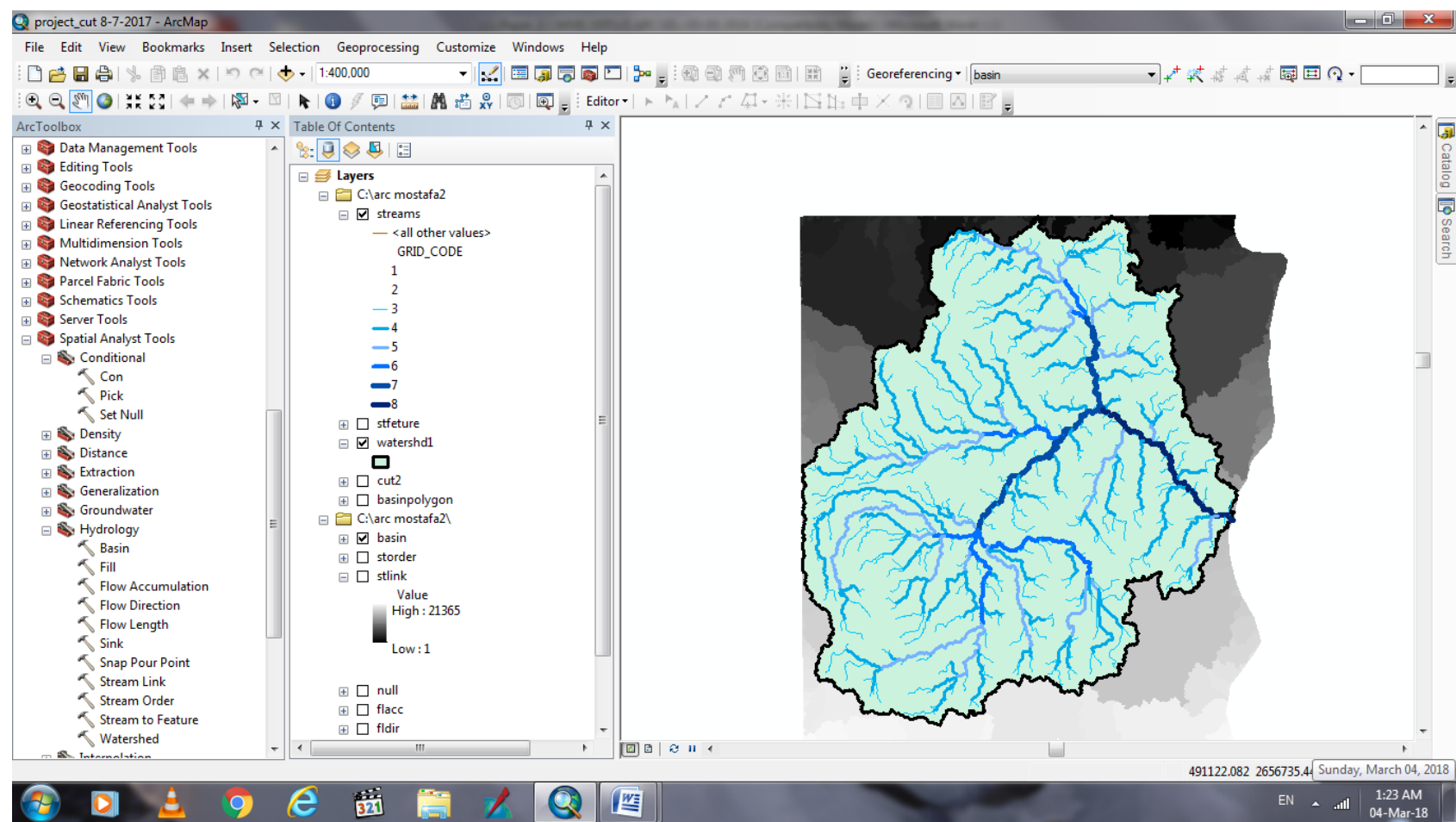

\section{RESULTS AND ANALYSIS}

From the previous section, it is concluded that the ARC GIS is used to delineate the boundary of the watershed and the area was found to be $1495 \mathrm{~km}^{2}$. On the other hand, WMS model is based on required determination of outlet station and the area of the watershed was found to be $2227 \mathrm{~km}^{2}$. It is also observed that the area determined by the ARC GIS is nearly similar to the area extracted from the topographic map (base reference).

\section{$\underline{\text { References }}$}

1 - Osnos, Evan. "Faust, China, and Nuclear Power," The New Yorker, Wednesday October 12, 2011. Retrieved at http://www.newyorker.com/online/blogs/evanosnos/2011/10/faust-chinaand-nuclear-power.html on October 12, 2011. Archived March 13, 2016, at the Wayback Machine.

2 - "Aswan High Dam". Carbon Monitoring for Action. Retrieved 2015-01-15.

3 - Latif, A. F. A. (1984) Lake Nasser The new man-made lake in Egypt (with reference to Lake Nubia)."Ecosystems of the World 23, Lakes and Reservoirs" (ed. F. B. Taub), pp. 385410. Elsevier Publishing Co., Amsterdam-Oxford-New York-Tokyo.

4 - Elewa, A. S. (1985) Hydrobiologia, 128: 249254.

5 - Intermap Digital Surface Model: accurate, seamless, wide-area surface models". Archived from the original on 2011-09-28.

6 - Jump up^ Li, Z., Zhu, Q. and Gold, C. (2005): title=Digital terrain modelling: principles and methodology|. CRC Press. Boca Raton.

7 - Madurika, HKGM; Hemakumara, GPTS (2017). "Gis Based Analysis For Suitability Location Finding In The Residential Development Areas Of Greater Matara Region". International Journal of Scientific \& Technology Research. 4 (8): 96-105. 
8 - Geographic Information Systems as an Integrating Technology: Context, Concepts, and Definitions". Kenneth E. Foote and Margaret Lynch, The Geographer's Craft Project, Department of Geography, The University of Colorado at Boulder. Retrieved 21 Apr 2015.

9 - Edsel, B.D.; et al. (2011). "Watershed Modeling and its Applications: A State-of-the-Art Review" (PDF). The Open Hydrology Journal. 5: 26-50.

10 -WMS Supported Models". Aquaveo. Archived from the original on January 24, 2017. Retrieved January 24, 2017. 